\title{
PENGARUH METODE COOPERATIVE LEARNING TEKNIK TWO STAY TWO STRAY DAN MEDIA KOMIK TERHADAP PEMAHAMAN KESEHATAN REPRODUKSI (Studi Kuasi Eksperimen pada Siswa Kelas VIII SMP 9 Tambun Selatan)
}

\author{
Laura Oma Setia ${ }^{1}$ \\ Dra. Atiek Sismiati S. ${ }^{2}$ \\ Dr.Aip Badrujaman ${ }^{3}$
}

\begin{abstract}
Abstrak
Penelitian ini bertujuan untuk mengetahui pengaruh metodecooperative learning teknik two stay two stray dan media komik terhadap pemahaman kesehatan reproduksi peserta didik Kelas VIII di SMPN 9 Tambun Selatan.Metodepenelitian yang digunakan adalah metodekuasi eksperimen, dengan desainNonequivalent Control Group Design pretest.Pengumpulan data dilakukan dengan menggunakan tes pemahaman berbentuk multiple choice dengan angka realibilitas0,87.Berdasarkan pengukuran normalitas dan homogenitas didapatkan bahwa semua data normal dan homogen. Hasil uji hipotesis menggunakan rumus independent sample t-testmenunjukan bahwa HO ditolak dan H1 diterima, yaitu terdapat pengaruh penggunaan metode Cooperative Learningteknik Two Stay Two Stray dan media komik terhadap pemahaman kesehatan reproduksi.
\end{abstract}

Kata kunci: metode cooperative learning teknik two stay two stray, media komik, pemahaman kesehatan reproduksi.

\section{Pendahuluan}

Menurut Santrock (2003) masa remaja (SMP) biasanya diawali dengan perkembangan biologis seperti perubahan fisik yang meliputi pertumbuhan tinggi, berat badan, dan kematangan seksual.Terjadinya kematangan seksual pada masa remaja, memicu timbulnya permasalahan terkait kesehatan reproduksi.Studi pendahuluan dilakukan peneliti di SMP 9 Tambun Selatan. Berdasarkan hasil wawancara dengan 10 peserta didik diketahui, 6 peser- ta didik menjelaskan arti kesehatan reproduksi sebagai proses berkembang biak. Delapan peserta didik tidak berani bertanya mengenai perkembangan fisiknya kepada orangtua. Enam peserta didik pernah berpacaran, 3 peserta didik pernah melakukan kontak fisik di bibir dan pipi, sedangkan 3 peserta didik lainya hanya berpegangan tangan. Dalam jangka waktu 5 tahun terakhir, terjadi 2 kali kasus peserta didik hamil di luar nikah. Hasil wawancara dengan guru BK diketahui metode dan media yang sering digunakan pada bimbingan klasikal yaitu

\footnotetext{
1 Mahasiswa Jurusan Bimbingan dan Konseling FIP UNJ, lauraomasetia@gmail.com

2 Dosen Bimbingan dan Konseling FIP UNJ, Atiek.sismiati@yahoo.com

3 Dosen Bimbingan dan Konseling FIP UNJ, Aip_bj@yahoo.com
} 
metode ceramah. Oleh karena itu diperlukan pemilihan metode dan media yang menarik, efektif, dan sesuai dengan kebutuhan peserta didik pada layanan bimbingan klasikal.

Salah satu teknik metode Cooperative Learning yaitu teknik Two Stay Two Stray. Teknik Two Stay Two Stray (TSTS), adalah teknik yang memberikan kesempatan kepada kelompok membagikan hasil dan informasi kepada kelompok lain. Penggunaan teknik layanan yang tepat harus disertai dengan penggunaan media yang menarik dan sesuai dengan teknik yang digunakan. Peneliti memilih media komik, karena komik membuat pesan yang besar tetapi disajikan secara ringkas dan mudah dicerna, dan dilengkapi dengan bahasa verbal yang dialogis.

Berdasarkan hasil studi pendahuluan dan latar belakang yang telah peneliti sampaikan, maka peneliti menganggap perlu melakukan penelitian. Rumusan penelitian ini ialah "Apakah terdapat pengaruh metode Cooperative Learning teknik Two Stay Two Stray dan Media Komik terhadap pemahaman peserta didik kelas VII di SMP 9 Tambun Selatan me-ngenai kesehatan reproduksi". Tujuan penelitian ini untuk mengetahui apakah Apakah terdapat pengaruh metode Cooperative Learning teknik Two Stay Two Stray dan Media Komik terhadap pemahaman peserta didik kelas VII di SMP 9 Tambun Selatan mengenai kesehatan reproduksi.

\section{Kajian Teori}

Remaja Sekolah Menengah Pertama (SMP) merupakan individu yang berada pada masa remaja madya.Dimana pada masa itu peserta didik harus mencapai tugas perkembanganya, menurut Havigurs salah satu tugas perkembangan peserta didik yaitu menerima kesadaran fisik dan menggunakanya secara efektif. Menurut Santrock (2003) masa remaja adalah masa eksprolasi seksual dan mengintegrasikan seksualitas.Para remaja memiliki rasa ingin tahu yang tinggi mengenai materi seks. Remaja berusaha mengembangkan identitas seksual yang matang, serta rentan dan bingung dalam perjalanan seksualnya

Pada masa remaja ini, seseorang telah mencapai kematangan fisik, terjadinya kematangan organ-organ reproduksi, dimana individu sudah dapat menghasilkan keturunan.Pada aspek kognitif, keingin-ta- huan remaja cukup tinggi dan membutuhkan informasi terutama yang berkaitan dengan kesehatan reproduksi.

Kesehatan reproduksi menurut Yani Widyastuti (2009) kesehatan reproduksi yaitu suatu keadaan sejahtera fisik, mental dan sosial secara utuh, tidak semata-mata bebas dari penyakit ayau kecacatan dalam semua hal yang berakitan dengan sistem reproduksi, serat fungsi dan prosesnya. Maka diperlukan pemberian informasi oleh pihak sekolah selaku institusi pada tingkat SMP dikarenakan pada tingkat ini remaja sedang pada masa transisi dari anak-anak ke remaja dan mengalami banyak perubahan dari segi fisik maupun emosional.

Salah satu cara pemberian informasi mengenai kesehatan reproduksi adalah melalui layanan bimbingan klasikal di sekolah. Bimbingan klasikal menurut Winkel dan Hastuti (2006) merupakan istilah yang khusus digunakan di institusi pendidikan sekolah dan menunjuk pada sejumlah siswa yang dikumpulkan bersama untuk kegiatan bimbingan. Dalam layanan ini pemberian informasi diberikan kepada banyak peserta didik sekitar 30-40 peserta didik.Untuk itu diperlukan keterampilan guru BK didukung dengan media dan metode yang tepat dalam menyampaikan materi yang efektif, efisien dan menyenangkan bagi peserta didik agar layanan ini sesuai dengan kebutuhan dan tugas perkembangan peserta didik.

Metode Cooperative Learning teknik Two Stay Two Stray dipilih oleh peneliti untuk meningkatkan pengetahuan peserta didik mengenai kesehatan reproduksi, karena memiliki banyak keuntungan yaitu dapat merangsang peserta didik untuk belajar secara berkelompok, berdiskusi sehingga terbangun pemahaman yang baik. Proses belajar yang terjadi melalui tukar pendapat maupun adu argumen, memberikan kesempatan bagi peserta didik untuk menjelaskan apa yang dipahaminya kepada orang lain. Teknik Two Stay Two Stray (TSTS) menurut Lie (2002) adalah memberikan kesempatan kelompok untuk membagikan hasil dan informasi dengan kelompok lain. Dengan demikian, diharapkan siswa dapat mengungkapkan pendapat di dalam kelompoknya maupun dalam kelompok lain.

Media komik dipilih karena tidak hanya memberikan peserta didik untuk mengoptimalkan otak 
kiri yang bersifat analitis, logis dan objektif tetapi juga sekaligus meningkatkan fungsi otak kanan dengan memberikan masalah yang menuntut pemecahan secara kreatif dan imajinatif tinggi. Menurut Scott McCloud (2008) komik adalah gambargambar dan lambang-lambang lain yang berdekatan atau bersebelahan dalam urutan tertentu, bertujuan untuk memberikan informasi dan mencapai tanggapan dari pembaca. Selama interaksi menggunakan Teknik Two Stay Two Stray dan media komik, peserta didik mengalami peningkatan pemahaman dimana peserta didik mendapat pencerahan karena peserta didik secara aktif mengkaitkan seluruh gagasan baru.

\section{Metode Penelitian}

Penelitian ini dilaksanakan di SMP Negeri 9 Tambun Selatan pada tahun ajaran 2013-2014. Penelitian ini dilaksanakan dari bulan November 2013 sampai dengan April 2014 Metode yang digunakan dalam penelitian ini adalah metode Quasi eksperiment. Desain eksperimen ini adalah Nonequivalent Control Group Design, karena sampel yang diambil tidak secara acak melainkan karena subjek telah alami membentuk suatu kelompok Desain eksperimen dilaksanakan dengan menggunakan satu kelompok eksperimen yang diberi perlakuan dan satu kelompok kontrol untuk perbandingan yang tidak diberikan perlakuan.

Menurut Arikunto (2002) Populasi adalah keseluruhan objek penelitian.Populasi dalam penelitian ini adalah seluruh peserta didik kelas 8 SMP Negeri 9 Tambun Selatan.teknik pengambilan sampel yang digunakan adalah teknik cluster sampling atau sampel berkelompok. Dalam sampel berkelompok peneliti memilih sejumlah kelas secara acak. Dengan demikian sampel dalam penelitian ini berjumlah 64 peserta didik, dengan rincian 32 peserta didik dari kelas eksperimen dan 32 siswa kelas kontrol.

Pengumpulan data dilakukan melalui tes. Instrument yang digunakan untuk mengukur pemahaman mengenai kesehatan reproduksi adalah berupa tes tertulis yang berbentuk pilihan majemuk. Setelah dilakukan uji validitas diperoleh hasil jumlah item yang valid sebanyak 38 butir.Berdasarkan uji kesukaran butir soal yang mempunyai taraf kesukaran sulit sebanyak 8 butir soal, butir soal yang mempu- nyai taraf sedang yaitu sebanyak 45 butir soal. Sedangkan berdasarkan uji beda butir soal yang mempunyai daya beda jelek yaitu sebanyak 14 butir soal, butir soal yang mempunyai daya beda cukup yaitu sebanyak 26, butir soal yang mempunyi daya beda baik yaitu sebanyak 14 butir soal. Angka reliabilitas yang diperoleh berdasarkan perhitungan dengan rumus KR-20 sebesar 0,87.

Uji Hipotesis dalam penelitian ini dilakukan dengan menggunakan rumus uji-t (independent sample t-test) pada program SPSS versi 16.0. Uji-t dilakukan terhadap dua kelompok yang diambil dari satu populasi dengan membandingkan dua nilai rerata yang merupakan suatu angka atau koefisien yang melambangkan derajat perbedaan mean.

\section{Hasil dan Pembahasan}

Pada saat pre test nilai rata-rata peserta didik kelas eksperimen adalah 18,09 sedangkan rata-rata peserta didik pada kelas kontrol sebesar 17,12 sehingga diperoleh selisih rata-rata nilai antara kelas eksperimen dan kelas kontrol adalah sebesar 0,97. Berdasarkan hasil pre test dapat disimpulkan bahwa kemampuan peserta didik pada kelas eksperimen dan kelas kontrol tidak berbeda jauh dengan kelas eksperimen. Kemudian kelas eksperimen diberikan perlakuan dengan menggunakan Teknik Two Stay Two Stray dan media komik, sedangkan kelas kontrol dengan metode ceramah. Setelah itu, dilakukan post test dengan jumlah soal yang sama pada kelas eksperimen dan kelas kontrol didapatkan hasil bahwa rata-rata nilai peserta didik pada kelas eksperimen yaitu 24,78 dan pada kelas kontrol yaitu sebesar 20,37 dengan selisih nilai rata-rata antara kelas eksperimen dan kelas kontrol yaitu 4,41.

Berdasarkan data nilai pre test dan post test di atas dapat diketahui bahwa terjadi peningkatan nilai rata-rata pemahaman peserta didik pada kelas eksperimen sebesar 6,69. Berdasarkan data pre test dan post test maka dapat diketahui rata-rata gain score kelas eksperimen yaitu sebesar 6.68. Gain score terbesar yaitu 10, sedangkan gain score terkecil yaitu 4. Berdasarkan hasil pre test dan post test pada kelas kontrol diketahui rata-rata gain score yaitu 3.59. Gain Score terbesar yaitu 6, sedangkan gain score terendah yaitu 1 .

Dengan demikian dapat disimpulkan bahwa ter- 
dapat peningkatan nilai rata-rata pada kelas eksperimen setelah diberikan perlakuan.Artinya teknik Two Stay Two Stray dan media komik yang digunakan pada kelas eksperimen dapat meningkatkan pemahaman peserta didik pada suatu konsep atau materi bimbingan.

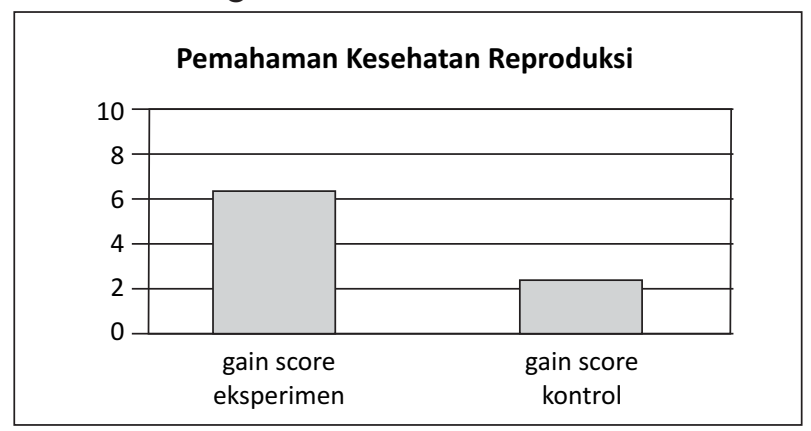

Grafik 4.3
Perbandingan Gain Score Kelas Eksperimen
dan Kelas Kontrol

Pada penelitian ini dilakukan analisis data untuk menguji normalitas data, homogenitas dan menguji hipotesis.. Langkah pertama yaitu melakukan uji persyarata data, yaitu uji normalitas dengan uji Kolmogrov-Smimov dengan alat yang digunakan untuk menghitung SPSS versi 16.0 dan uji Homogenitas Tes of Variance dengan alat yang digunakan untuk menghitung SPSS versi 16.0. Berdasarkan perhitungan uji normalitas gain score pada kelas eksperimen didapatkan nilai signifikansi $(0,06)>(0,05)$ berarti data berdistribusi normal pada kelas eksperimen. Sedangkan uji normalitas gain score kelas kontrol yaitu $0,32>(0,05)$ artinya data berdistrubusi normal. Hasil uji homogenitas didapatkan nilai signifikansi untuk gain score pada kelas eksperimen dan gain score pada kelas control yaitu 0,93 berarti $(0,93<0.05)$ artinya gain score pada kelas eksperimen dan gain score pada kontrol homogen.

Setelah dilakukan uji persyaratan data maka dilakukan uji hipotesis menggunakan uji-t independent Sample t-Test dengan menggunakan SPSS versi 16.0.Berdasarkan hasil perhitungan diperoleh nilai signifikansi sebesar 0.000 yang berarti $(0.000)<$ $\alpha$ (0.05), maka H0 ditolak. Dengan demikian dapat disimpulkan bahwa kelas eksperimen memiliki pemahaman mengenai Kesehatan reproduksi lebih tinggi secara signifikan dibandingkan dengan kelas kontrol. Berdasarkan hasil pengujian hipotesis tersebut diketahui bahwa, terdapat pengaruh positif sig- nifikan dari metode Two Star Two Stray dan media komik.

Pertemuan dalam penelitian ini berjumlah 6 (enam) kali pertemuan. Pertemuan pertama digunakan untuk perkenalan, pemaparan langkah-langkah Two Stay Two Stray, serta membagi-bagi peserta didik menjadi 7 kelompok. Setiap kelompok beranggotakan 4-5 orang. Kemudian peneliti memberikan komik kepada masing-masing kelompok dengan materi yang berbeda yaitu pengertian kesehatan reproduksi, perubahan fisik remaja laki-laki, perubahan fisik remaja perempuan, nama dan fungsi organ reproduksi perempuan, nama dan fungsi organ reproduksi laki-laki, merawat organ reproduksi laki-aki. Peserta didik pada pertemuan ini antusias dan tertarik ketika mendapatkan materi berupa komik kesehatan reproduksi, tetapi kelompok tidak dibentuk secara heterogen berdasarkan kemampuan akademiknya. Pada pertemuan ini peserta didik masih sulit diatur dan suasana kelas sangat ramai.

Pada pertemuan kedua kegiatan awal dimulai pembukaan salam, presentasi, ketika praktikan mengarahkan peserta didik untuk berkumpul dalam kelompoknya kondisi kelas terlihat ramai dan membutuhkan waktu 5 menit untuk berkumpul dalam kelompok masing-masing. Praktikan mengarahkan dua peserta didik dari masing-masing kelompok untuk bertamu pada kelompok-kelompok lain dan menginstruksikan dua orang peserta didik pada masing-masing kelompok untuk berdiam dalam kelompok. Pada saat pelaksanaan para peserta didik terlihat bingung dan banyak bertanya mengenai langkah-langkah pada temanya, mereka terlihat bingung dalam menentukan siapa peserta didik yang tinggal dalam kelompok serta peserta didik bertamu dengan waktu setiap kelompok 15 menit. Pada saat berdiskusi masing-masing peserta didik terlahat cukup aktif dalam menjelaskan, tetapi hanya beberapa peserta didik yang bertanya.

Pada pertemuan ketiga praktikan kembali menginstruksikan peserta didik untuk berkumpul pada masing-masing kelompok, peserta didik tidak ramai dan ricuh seperti pertemuan sebelumnya. Praktikan mengarahkan dua peserta didik dari masing-masing kelompok untuk bertamu pada kelompok-kelompok lain yang belum mereka datangi. Pada saat pelaksanaan para peserta didik tidak terlihat bingung, mere- 
ka langsung bergerak ke kelompok lain tanpa berdebat banyak mengenai anggota yang menjadi tamu atau yang tinggal dalam kelompok. Proses diskusi lebih lancar dan aktif hanya saja ketika berpindah ke kelompok lain peserta didik terlihat ramai.

Pada pertemuan keempat tidak berbeda dengan pertemuan kedua dan ketiga. Pada pertemuan ini peserta didik tertib dalam melakukan kegiatan yang diinstruksikan praktikan, tidak ramai. Para peserta didik ketika menghampiri kelompok lain langsung memulai diskusi, dan aktif. Pada saat membuat kesimpulan banyak peserta didik mengajukan dirinya tanpa harus ditunjuk oleh praktikan terlebih dahulu.

Pada pertemuan kelima, praktikan mengarahkan peserta didik untuk bergabung dalam kelompoknya. Praktikan menginstruksikan para peserta didik dalam kelompoknya masing-masing untuk saling mencocokan dan membahas hasil kerja masing-masing.Peserta didik tertib dalam melaksanakan kegiatan, aktif dan saling bertanya kepada teman sekolompoknya. Terlihat beberapa peserta didik malah bertanya pada kelompok lain mengenai hasil diskusi mereka. Pada akhir pertemuan praktikan menginstruksikan masing-masing kelompok untuk menyiapkan hasil diskusi untuk dipresentasikan pada pertemuan selanjutnya.

Pada pertemuan keenam masing-masing kelompok diinsntruksikan untuk mempresentasikan hasil diskusi masing-masing kelompok selama 5 menit, beberapa kelompok tertentu hanya beberapa perwakilan yang menjelaskan hasil diskusi. Pada akhir pertemuan praktikan menyimpulkan hasil kegiatan.

Pemahaman kesehatan reproduksi pada kelas eksperimen lebih tinggi dibandingkan dengan kelas kontrol karena dalam kelas eksperimen menggunakan metode Cooperative Learning teknik Two Stay Two Stray yang mendorong peserta didik untuk bertanggungjawab atas materi yang dimiliki, mendorong peserta didik untuk aktif, saling membantu memecahkan masalah, saling mendorong untuk berpretasi, teknik ini juga melatih peserta didik untuk bersosialisasi.

Berdasarkan hasil penelitian ini diketahui media komik dapat meningkatkan pemahaman kesehatan reproduksi. Komik mempunyai sifat yang sederhana dalam penyajianya, dan memiliki unsur urutan ceri- ta yang membuat pesan yang besar tetapi disajikan secara ringkas dan mudah dicerna, terlebih lagi ia dilengkapi dengan bahasa verbal yang dialogis. Dengan adanya perpaduan antara bahasa verbal dan nonverbal, mempercepat peserta didik paham terhadap isi pesan.

Berdasarkan observasi yang dilakukan peneliti selama memberikan perlakuan menggunakan teknik Two Stay Two Stray dan media komik, siswa memiliki ketertarikan dengan media komik yang diberikan saat perlakuaan, siswa terlihat sangat aktif dan bekerjasama saat perlakuan teknik Two Stray Two Stray.

\section{Simpulan dan Saran}

Berdasarkan data yang diperoleh, terdapat peningkatan pemahaman peserta didik mengenai kesehatan reproduksi. Sebelum perlakuan dengan menggunakan teknik Two Stay Two Stray dan media komik, rata-rata skor pemahaman siswa pada kelas eksperimen yaitu sebesar 18,09. Setelah diberikan perlakuan dengan menggunakan teknik Two Stay Two Stray dan media komik, rata-rata skor pemahaman peserta didik pada kelas eksperimen meningkat yaitu 24,78 . Peningkatan rata-rata gain score sebelum dan sesudah perlakuan yaitu sebesar6.68. Dengan kata lain, pemahaman peserta didik mengenai kesehatan reproduksi lebih tinggi sesudah diberikan perlakuan dengan menggunakan teknik Two Stay Two Stray dan media komik.

Bagi peneliti lain yang akan melaksanakan penelitian pada metode cooperative learning teknik two stay two stray dan media komik, agar kelompok berjalan secara dinamis maka kelompok dibentuk secara heterogen berdasarkan kemapuan akademiknya. 


\section{Referensi}

Benjamin, S. Bloom. (1956). Taxonomi of Educational Objectives, Canada: David McKay Company

Badan Kepedudukan dan Keluarga Berencana Indonesia. (2012) Survei Demografi dan Kesehatan Indonesia, Jakarta: Badan Pusat Statistik.

Lie, Anita. (2002)Cooperative Learning, Jakarta :Grasindo

Mcloud. Scott. (2008). Memahami Komik, Jakarta: KPG.

Suharsimi, Arikunto. (2002). Prosedur Penelitian Suatu Pendekatan Praktik, Jakarta: Rineka cipta.
Sutrock, John w.(2003). Adolescence. Perkembangan Remaja terjemahan Shinto Adelar dan Sherly Saragihc, Jakarta :Eirlangga

Suprijono, Agus. (2013). Cooperative Learning Teori dan Aplikasi PAIKEM, Yogyakarta; Pustaka Pelajar.

Widyastuti,Yani. (2009). Kesehatan Reproduksi, Jakarta: Fitrayama.

Wingkel, W. S dan Sri Hastuti, (2006).Bimbingan dan Konseling di Institusi Pendidikan, Yogyakarta: Media Abadi. 